Logos Universality Mentality Education Novelty: Political Sciences and European Studies

ISSN: 2284-5968 | e-ISSN: 2501-0417

Covered in: ERIH PLUS, CEEOL, HeinOnline, Index Copernicus, CrossRef, CrossCheck, J-Gate, Google Scholar, Ideas RePeC, Econpapers, Socionet, KVK, WorldCat.

2020, Volume 6, Issue 2, pages: 62-64 | doi: 10.18662/lumenpses/6.2/24

\section{Review of the}

Volume “Asistența

socială şi

religiozitatea la

persoanele cu

handicap" [Social

Work and

Religiosity for

People with

Disabilities],

Author: Carmen

Gabriela Mândrilă-

Lăzăreanu, Lumen

Publishing House, 2020

\section{Iulian APOSTU1}

${ }^{1} \mathrm{PhD}$, Scientific Researcher, Institute of Sociology, Romanian Academy, phdiulian@gmail.com
Abstract: The book "Asistența socială şi religiozitatea la persoanele cu handicap" [Social work and religiosity for people with disabilities], authored by Carman Gabriela Mândrilă Lăzăreanu, published by Lumen Publishing House from Iasi, Romania, in 2020, aims from the beginning to be an important guide for young generations, developing both the secular dimension of social work and the religious dimension, specific to theological environments. We welcome the publishing of the book, especially since social discourses and, unfortunately, those of some Romanian public personalities blame the vulnerable condition of the people who depend on financial benefits and other types of intervention and support services. In this sense, the book clarificaties from the beginning the importance of changing mentalities, norms and how these people are perceived, for a solution to the problems they face. Approached in terms of cause and effect, the volume focuses on the social, psychological, medical and legal dimensions that define the situation of disability in order to build an objective framework for assessing and supporting the condition of disability.

Keywords: disability, stigma, social work, social services, family, Carmen Gabriela Mândrilă Lăžăreanu.

How to cite: Apostu, I. (2020). Review of the Volume "Asistența socială şi religiozitatea la persoanele cu handicap" [Social Work and Religiosity for People with Disabilities], Author: Carmen Gabriela Mândrilă-Lăzăreanu, Lumen Publishing House, 2020. Logos Universality Mentality Education Novelty: Political Sciences and European Studies, 6(2), 62-64. doi: 10.18662/lumenpses/6.2/24 
The significant increase in the number of people affected by various diseases with difficult consequences both physically and mentally requires the attention of specialists in different fields to treat, mitigate the effects and, at the same time, support them through various intervention programs specific to social work. Thus, from the perspective of social work services, a series of methods and techniques have been developed and improved over time to improve the life of socially assisted people through a type of strategies that recover the autonomy of the assisted person and not make them dependent on the system.

The paper is structured in five chapters and the distribution of ideas shows the author's attention to detail. She develops her ideas (Mândrilă Lăzăreanu, 2020) starting from the social image of the disability condition, insisting on the issue of stigmatization, marginalization and social representations of people with disabilities.

Thus, as an effect of the degradation of interpersonal relationships, the condition of disability is still viewed marginally in certain environments. For this reason, the very self-perception of people with disabilities is appropriate. In this sense, through the prism of sociological theories (Goffman, 1990), the author highlights a series of social identities of people with disabilities from the perspective of stigma. For this reason, the stigma, as an attribute that discredits, appears as a discrepancy between the real identity of the person and the one that is unjustly attributed to them. Based on them, a series of individuals from the dominant group build a theory of stigma, an ideology that serves to explain the inferiority of people with disabilities, warning about the potential dangers they represent on the social environment, on the national budget etc.

Another chapter of the book is dedicated to the typological aspects that define the condition of disability, both neuro-motor and sensory. This form of approach is commendable as the author manages to explain difficult concepts from psychology, psychiatry, medicine in a language accessible to some extensive categories of readers.

Also, another chapter of a great psycho-social load develops the issue of the evolution environment and the psycho-social interferences in the developmental stages of the person classified in a certain degree of disability, of course, insisting with priority on family environments. The author highlights the main trends that can influence the development and social integration of people with disabilities and, of course, can create difficulties on intervention strategies in social work: hyper-protective behavior of the family, the type of family structure (solidarity or conflict) and the social perception of the community about the family with 
disabilities. Moreover, against this background, the book develops topics that describe various social controversies regarding the marriage of people with a certain degree of disability or about the condition of increased vulnerability of disability in old age.

Appreciating, also from the perspective of theological dimensions, the author warnings that the warm figures and the smiles on the mother's face is an encouragement and a strong positive feeling as a response to the child in opposition to the negative reactions of others to the many failures of the child. In this sensitive context of interaction, the presence of God could be a support and the spiritual state of this relationship can help the person with disabilities to relate to Him, beyond any barrier of their own vulnerability. In the spiritual setting of the Church, beyond the theological effects of prayer, it can also develop a psychological function through the added hope given by the person's trust in God.

As a whole, the book advocates a return to normalcy. It describes the condition of people classified in different degrees of disability, showing their typologies, specific elements and vulnerabilities. Its addressability to the young student population creates the premises for mentalities with a higher level of support for future generations. The book is valuable, extremely important due to the consistent volume of information that synthesizes technical elements from sociology, psychology, psychiatry and medicine. It is useful both for young people in university training but also for the general public for timely information on the phenomenon of disability.

\section{References}

Mândrilă Lăzăreanu, C. G. (2020). Asistențta socială și religio zitatea la persoanele cu bandicap [Social work and religiosity for people with disabilities]. Lumen. 